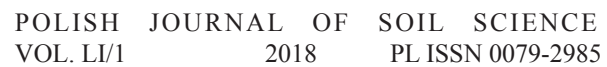

DOI: $10.17951 / \mathrm{pjss} / 2018.51 .1 .159$

KRYSTYNA CYBULSKA*, ILONA WROŃSKA*, KACPER RYGIELSKI*, MARTA KOWARSKA*

\title{
ASSESSMENT OF THE COMPOST MADE OF POULTRY POST- SLAUGHTER WASTE ON A BACKGROUND OF COMMERCIAL PREPARATIONS APPLYING THE PHYTOTOXKIT ANALYSIS
}

Received: 27.02 .2018

Accepted: 12.05 .2018

Abstract. One of the problems in the development of the agro-food industry is the production of enormous quantities of organic waste. In recent years, in order to minimize the negative impact of waste on the environment, emphasis is put on their recycling. Organic matter derived from poultry industry waste can be processed into other products, including compost.

The aim of the study was to evaluate the phytoremediation of selected plant species on the compost substrate obtained from the poultry waste as compared to other commercial composts available on the market. Analyses used the Phytotoxkit containing three test species: sorghum (Sorghum saccharatum), bittercress (Lepidium sativum) and white mustard (Sinapis alba). The test plants were placed on four different substrates: control soil, poultry compost, vermicompost and Compo Sana ${ }^{\circledR}$.

Phyto-reactivity of plants tested on compost prepared from poultry waste on a background of other commercial products was dependent on the plant species and the type of substrate. Poultry waste compost exhibited equally good nutritional properties in the composition of macro and micronutrients, which determined the growth and development of seedlings. It particularly refers to the stimulation of the growth of underground parts of mustard and bittercress, respectively $65 \%$ and $86 \%$ of the control value, and the aboveground parts, that were higher by $46 \%$ and $38 \%$, respectively.

Keywords: phytotoxkit, poultry compost, vermicompost, plants

* Department of Chemistry, Microbiology and Environmental Biotechnology, West Pomeranian University of Technology in Szczecin, Słowackiego 17 Str., 71-434 Szczecin, Poland, corresponding author: krystyna.cybulska@zut.edu.pl 


\section{INTRODUCTION}

Plant production in agriculture is based on respect for the principles aimed, among others, at maintaining or improving the fertility and productivity of soils through the use of appropriate agro-technology, plant protection and, above all, the rational mineral and organic fertilization. In view of the growing organic matter deficit in the soils, it is necessary to look for other sources of organic matter and biogenic components, including microelements (Gondek and Filipek-Mazur 2005). The application of waste-origin substances as fertilizers, even after their refining, should be carried out in accordance with the rules of well understood agrotechnics and compliance with the principles of environmental protection (pos. 2). Unconventional organic fertilizers include different types of compost (Baran and Martyn 1996, Bauduin et al. 1987, Cheng et al. 2007, Lekman et al. 1997). For many years, new biotechnology has been used to produce a high-quality organic fertilizer called vermicompost. It is produced in the process of composting the organic and industrial waste using the concentrated population of Eisenia fetida Sav., known under the name Californian (Kalembasa 1998). Various kinds of plant waste can be used for the production of compost and vermicompost, most of the sludge from biological wastewater treatment, peat, sawdust, lignite, food and meat waste and other waste materials of biological origin (Kalembasa 1998). Due to growing consumerism, more and more animals are being farmed on poultry farms. This generates large quantities of biological waste, which, according to applicable law, is subject to disposal. In order to recycle organic matter derived from poultry slaughterhouse waste, they are subjected to a variety of processes, including composting (Kopeć et al. 2014). The main feature of meat industry waste is the high proportion of organic compounds from $51 \%$ to $81 \%$, while protein content ranges from $5 \%$ to $68 \%$ and fat from 3\% to 38\% (Sobczak and Błyszczek 2009). These parameters indicate its good quality and can be used as organic fertilizer (Anders and Nowak 2008).

The legal possibilities for applying the composting process involving waste of animal origin are governed by Regulation (EC) No 1069/2009 of the European Parliament and Council of 21 October 2009 laying down health rules on animal by-products not intended for human consumption. In addition, it divides the waste into three categories defined by the level of hazard to humans and animals resulting from the above products, and outlines the principles and procedures for their management. Composting, i.e. organic recycling, is one of the methods for removing and reusing second and third category products. These categories provide for the possibility of introducing the compost on the market and use as organic fertilizers or soil improvers.

The aim of the study was to determine the reaction of test plants to compost from poultry slaughter waste in comparison with commercially available preparations. 


\section{MATERIALS AND METHODS}

The experiment has been made with Phytotoxkit. For this purpose, three species of test plants were used: Sorghum saccharatum, Lepidium sativum and Sinapis alba. Plants were incubated at $25^{\circ} \mathrm{C}$ with no light for three days on four different substrates: test soil, compost obtained from post-slaughter waste and two commercial substrates. Commercial composts included vermicompost (natural hummus of Californian worms) and Universal Super Light Compo Sana ${ }^{\circledR}$ substrate (manufacturer Compo $\mathrm{GmbH} \& \mathrm{Co} . \mathrm{KG}$ ). The length of the aboveground and underground parts of plants $(\mathrm{mm})$ was determined using the ImageJ software.

Achieved results were statistically analyzed using the Statistica 12 software. Statistical assessment was performed by means of ANOVA variance analysis. The significance of the differences between the mean root lengths and the aboveground parts within the individual plant species was verified applying Tukey's test. When the parameters had distribution different from the normal one or did not have the same variance, the significance of differences in mean values was verified using the Kruskal-Wallis test.

\section{RESULTS AND DISCUSSION}

On the basis of analyses of the impact assessment of different composts, including compost after poultry waste processing, there was a varied reaction of growth and development of test seeds such as: Sorghum saccharatum, Lepidium sativum and Sinapis alba (Fig. 1).

By determining the average length of the test plants roots $(\mathrm{mm})$ on the analyzed substrates, the amount of germinated seeds, as shown in Table 1, was taken into account. The Phytotoxkit test methodology was used for statistical analysis after 3 days of incubation (Fig. 2). Results showed a significant difference $(\mathrm{p}<0.05)$ of sorghum root length between control substrate and vermicompost. The root length of the sorghum on the vermicompost was by $21 \%$ lower than that of the control soil. There were no significant differences between control soil and other substrates. On the other hand, in the case of mustard, the inhibitory effects of poultry compost on the development of the root system have been demonstrated. The average root length was by $35 \%$ less than that of the control $(55.02 \mathrm{~mm})$. There were no significant differences between other composts analyzed. Vermicompost significantly reduced development of the cress root system. Significant root length differences were observed not only between the control substrate and vermicompost, but also between the vermicompost and Compo Sana ${ }^{\circledR}$ substrate. There were no statistically significant differences in the length of cress roots on the poultry compost on the background of the remaining analyzed substrates. 

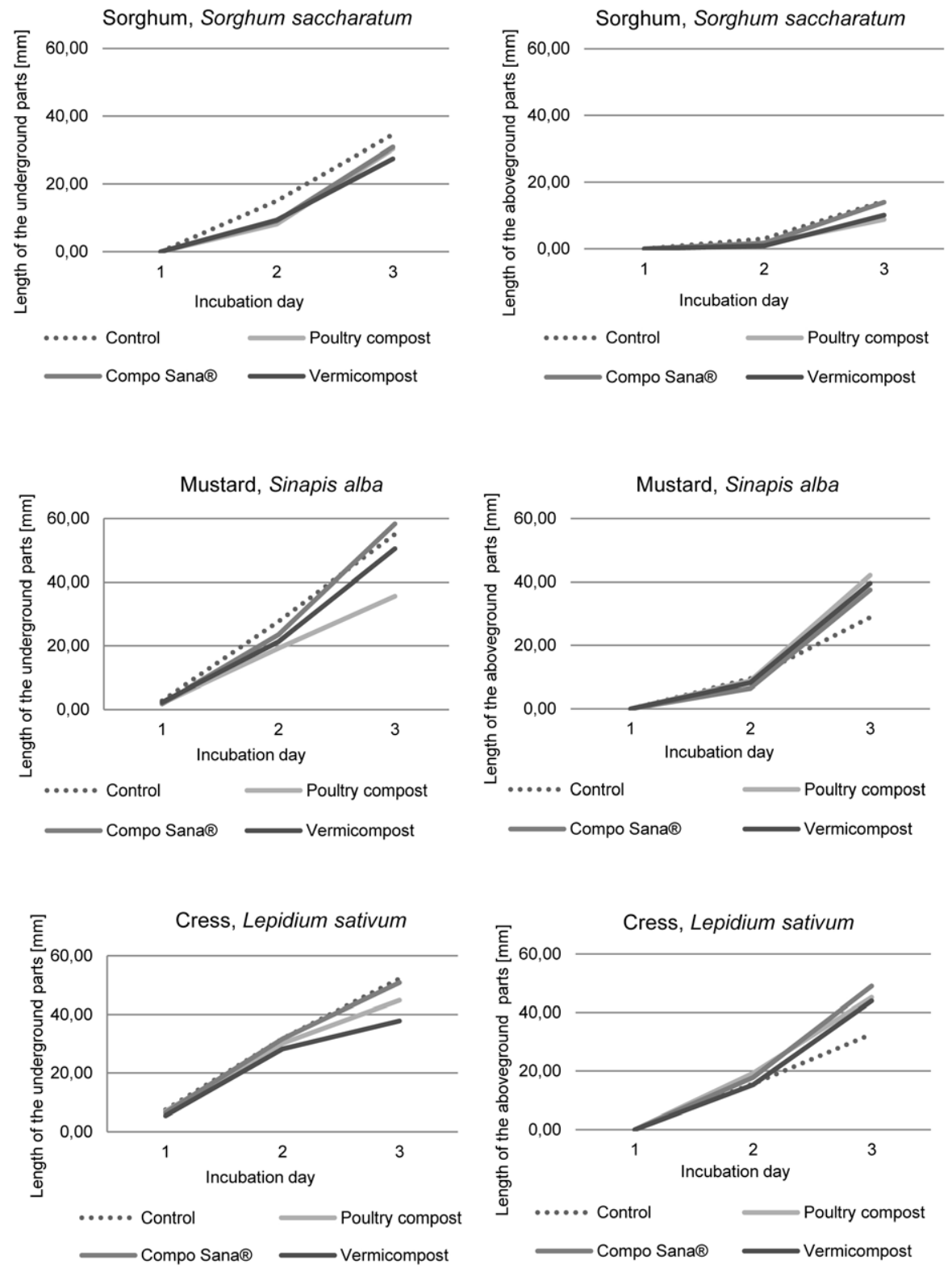

Fig. 1. Average length of the underground and aboveground parts of test plants on selected substrates during 3 days of incubation

By analyzing the growth of the aboveground parts of test plants after three days of incubation, it was found that the upper part of the sorghum was best developed on the control soil $(14.36 \mathrm{~mm})$ and the worst on the poultry compost. The average length of sorghum stalk on poultry compost was $39 \%$ lower as compared to the control. Statistical analysis showed a significant difference 

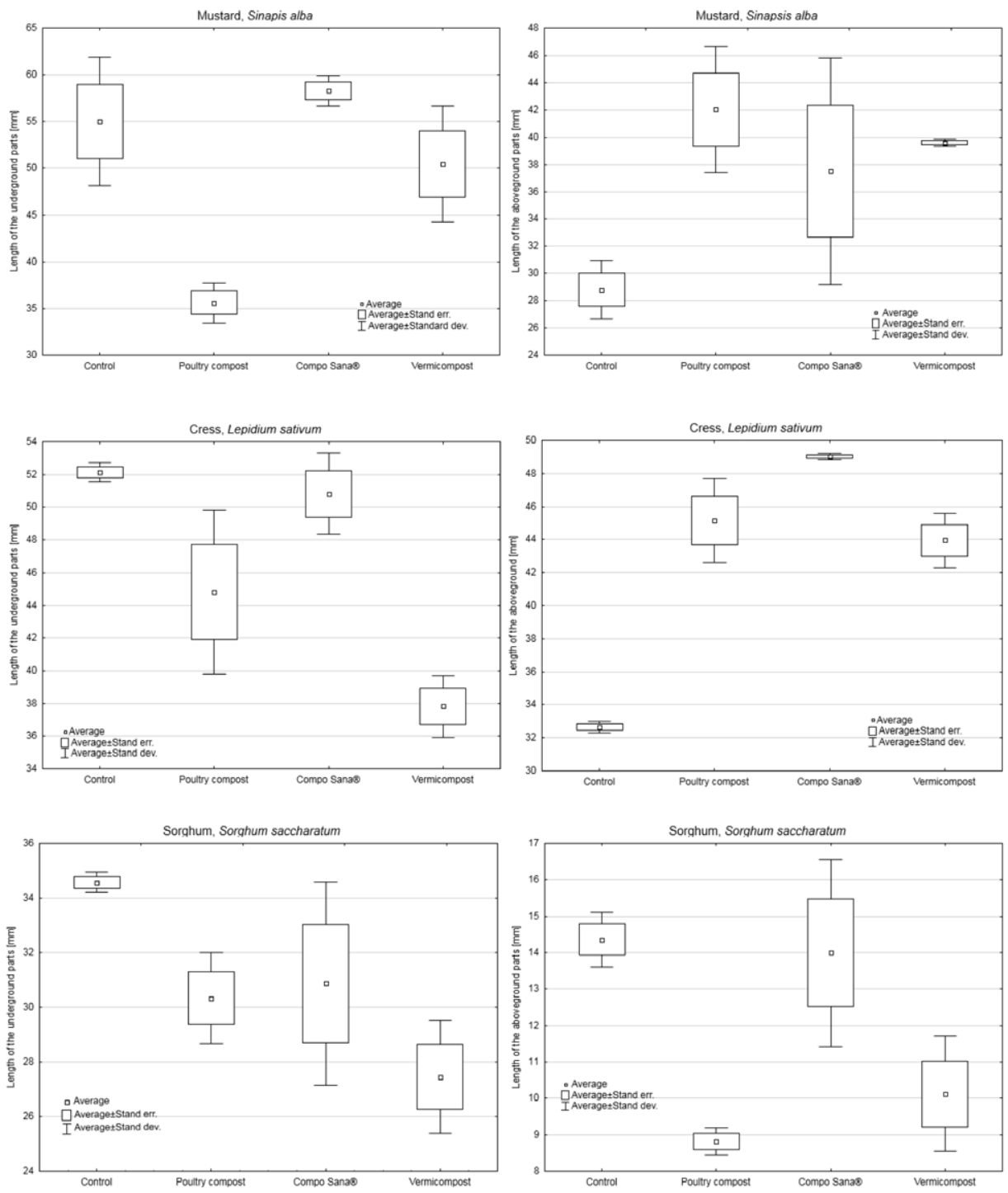

Fig. 2. Average length of underground and aboveground parts of test plants on selected substrates on day 3 of incubation

in the mean length of the sorghum aboveground part between control soil, poultry compost and vermicompost, where the length of the sorghum was by $30 \%$ lower than that of the control soil. It has also been shown that the length of the aerial part of sorghum on the poultry compost was significantly different from the Compo Sana ${ }^{\circledR}$ substrate, but was not different from the vermicompost.

In the case of the length of mustard stalk, a statistically significant difference was found between the control and the poultry compost. Mustard showed the lowest increase in the aboveground part on control soil $(28.80 \mathrm{~mm})$, while 
the largest increase was found on the poultry compost (Fig. 3). The average length of the mustard stalk on poultry compost was by $46 \%$ higher than that of the control. There was no difference between control and the remaining substrates tested.When analyzing the length of aboveground parts of cress, it was found that the control soil was significantly different between the tested substrates. On control soil, the cress was characterized by the smallest increase of stem length $(32.65 \mathrm{~mm})$, while the largest length of the aboveground parts of cress was recorded for Compo Sana ${ }^{\circledR}(49.02 \mathrm{~mm})$. The average length of the aboveground parts of cress on the Compo Sana ${ }^{\circledR}$ substrate was by $50 \%$ higher than that of the control. Cress on the poultry compost was characterized by a slightly lower stalk growth as compared to the Compo Sana ${ }^{\circledR}$ substrate. The average length of the aboveground parts of cress on poultry compost was 45.16 $\mathrm{mm}$, which was by $38 \%$ higher than the control soil and by $8 \%$ smaller as compared to the Compo Sana ${ }^{\circledR}$ substrate (Fig. 4). No statistically significant differences for cress were found between the poultry compost and the Compo Sana ${ }^{\circledR}$ substrate. The significant difference in the length of the cress stems was found between Compo Sana ${ }^{\circledR}$ substrate and vermicompost $(43.95 \mathrm{~mm})$.

Table 1. The amount of germinated plant seeds on the tested substrates

\begin{tabular}{ccccc}
\hline Plant & Control & Poultry waste & Compo Sana $^{\circledR}$ & Vermicompost $^{\circledR}$ \\
\hline $\mathrm{X}$ & & The maximum amount of plant seeds: 10 & \\
\hline $\begin{array}{c}\text { Sorghum, } \\
\text { Sorghum saccharatum }\end{array}$ & 8 & 10 & 10 & 10 \\
\hline $\begin{array}{c}\text { Mustard, } \\
\text { Sinapis alba }\end{array}$ & 10 & 10 & 10 & 10 \\
\hline $\begin{array}{c}\text { Cress, } \\
\text { Lepidium sativum }\end{array}$ & 10 & 9 & 9 & \\
\hline
\end{tabular}

The difference in germination ability of seeds on individual test substrates may be due to their different nutrient content, as confirmed by Atiyeh et al. (2000). The authors in their study showed differences in plant growth between different composts and vermicomposts. The researchers have also pointed out that the difference between different composting and the vermicomposting process may have a big impact. Farhad et al. (2009) in their studies have shown that the use of poultry manure is beneficial for maize growth and yield. This is due to the content of the desired nutrients in this organic fertilizer and the possibility of supplying organic matter to the soil. Similar studies using compost from slaughter waste for soybean and maize cultivation were conducted by Nunes et al. (2015). Mandal et al. (2013) found that composted poultry manure contributes to the improvement of physical and chemical properties of soil. Delgado et al. (2010) claimed that appropriate stability and maturity are extremely considerable traits of the poultry compost determining its use as a fertilizer. The authors also showed that the pro- 
cess of poultry manure composting reduces its phytotoxicity. An important parameter for the use of poultry manure as an organic fertilizer are its proper $\mathrm{C} / \mathrm{P}$ and $\mathrm{N} / \mathrm{P}$ ratios. It is, therefore, advisable to create a mixture of this material together with a green waste (Vandecasteele et al. 2014).
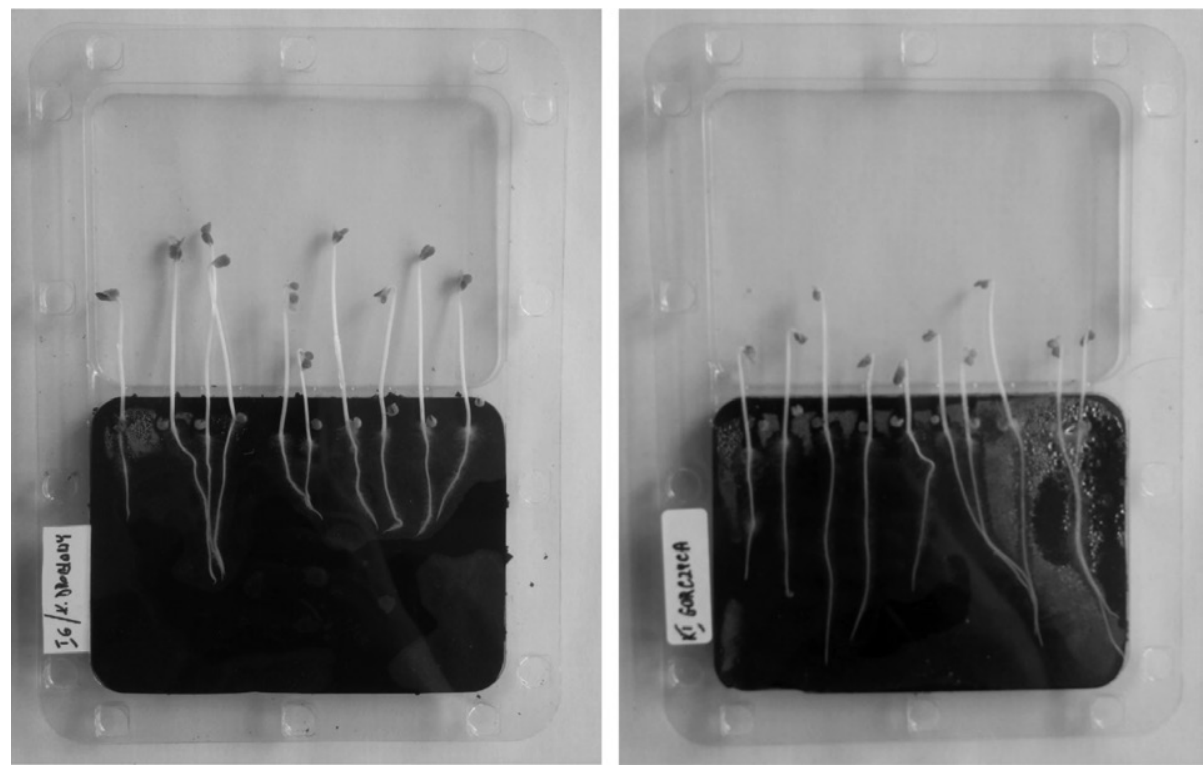

Fig. 3. Photo of mustard seedlings on poultry compost and control soil after 3 days of incubation (from the left: poultry compost, control soil)
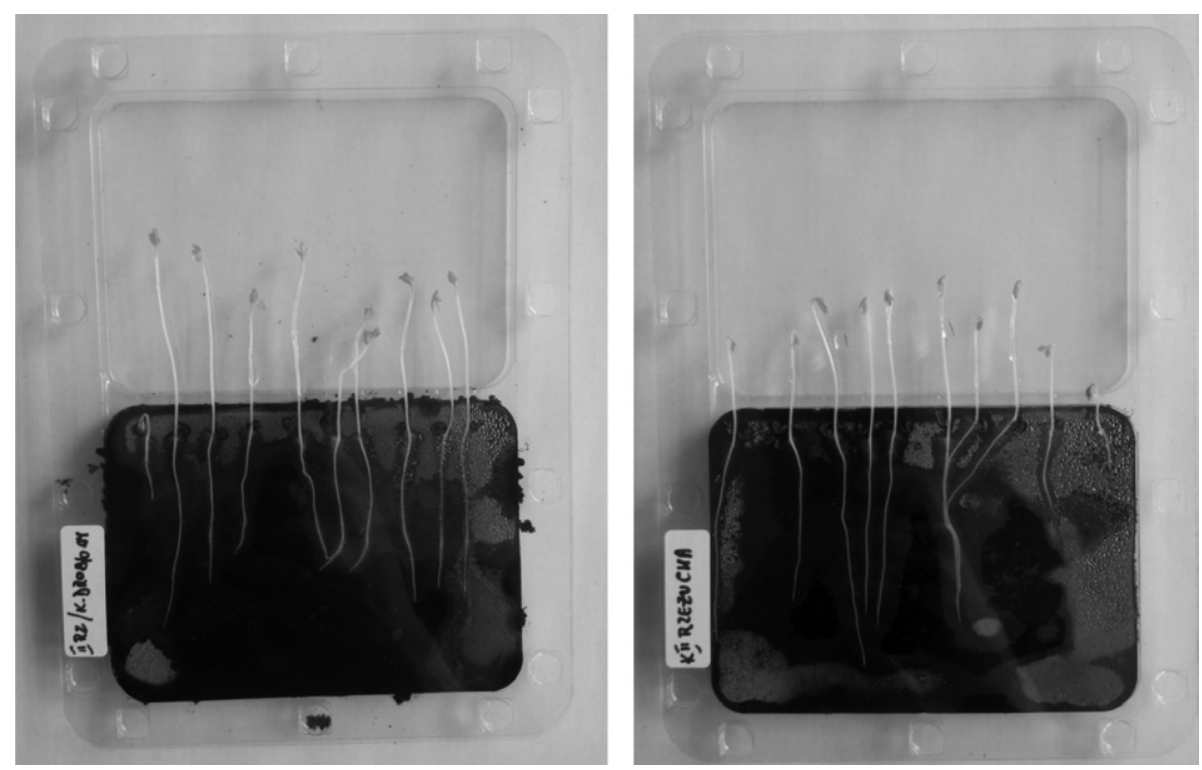

Fig. 4. Photo of cress seedlings on poultry compost and control soil after 3 days of incubation (from the left: poultry compost, control soil) 


\section{CONCLUSIONS}

1. The phyto-reaction of the tested plants was dependent on the plant species and the type of substrate including the compost prepared from the poultry waste.

2. The increase in the underground parts of mustard and cress on poultry compost was $65 \%$ and $86 \%$ of the control, respectively, and that of the aboveground parts was by $46 \%$ and $38 \%$ higher, respectively. The sorghum on the analyzed substrates showed a similar increase in the aboveground and underground parts as compared to the control.

3. In the first stage, the growth of test plants on poultry compost was not so intense as on other substrates.

\section{REFERENCES}

[1] Anders, D., Nowak, L., 2008. Assessment of composting process with animal waste share. Infrastructure and Ecology of Rural Areas, 9: 35-46.

[2] Atiyeh, R.M., Subler, S., Edwards, C.A., Bachman, G., Metzger, J.D., Shuster, W., 2000. Effects of vermicomposts and composts on plant growth in horticultural container media and soil. Pedobiologia, 44: 579-590.

[3] Baran, S., Martyn, W., 1996. The transformation of organic waste to compost (in Polish). Zeszyty Problemowe Postępów Nauk Rolniczych, 429: 33-36.

[4] Bauduin, M., Delcarte, E., Impens, R., 1987. Agronomic characterization and evaluation of two new municipal waste composts. In: Composts: production, quality and use. EAS London, New York, 479-486.

[5] Cheng, H.F., Xu, W.P., Liu, J.L., Zhao, Q.J., He, Y.Q., Chen, G., 2007. Application of composted sewage sludge (CSS) as a soil amendment for turfgrass growth. Ecological Engineering, 29: 96-100.

[6] Delgado, M.M., Martin, J.V., De Imperial, R.M., León-Cófreces, C., García, M.C., 2010. Phytotoxicity of uncomposted and composted poultry manure. African Journal of Plant Science, 4(5): 154-162.

[7] Farhad, W., Saleem, M.F., Cheema, M.A., Hammad, H.M., 2009. Effect of poultry manure levels on the productivity of spring maize (Zea mays L.). The Journal of Animal \& Plant Sciences, 19(3): 122-125.

[8] Gondek, K., Filipek-Mazur, B., 2005. Agrochemical evaluation of the fertilizer value of composts of different origin (in Polish). Acta Agrophysica, 5(2): 271-282.

[9] Kalembasa, D., 1998. The estimation of fertilizer value of vermicompost (in Polish). Zeszyty Naukowe AR w Krakowie, Sesja Nauk. 58 Ekologiczne i gospodarcze znaczenie dżdżownic, $155-160$.

[10] Kopeć, M., Gondek, K., Orłowska, K., Kulpa, Z., 2014. The use of poultry slaughterhouse waste to produce compost (in Polish). Ecological Engineering, 37: 143-150.

[11] Lekman, S., Winiarska, Z., Kacperek, K., 1997. Evaluation of the fertilizer value of municipal waste Dano composts (in Polish). Pamiętnik Puławski, 109: 73-86.

[12] Mandal, M., Chandran, R.S., Sencindiver, J.C., 2013. Amending Subsoil with Composted Poultry Litter-I: Effects on Soil Physical and Chemical Properties. Agronomy, 3: 657-669, DOI:10.3390/agronomy3040657. 
[13] Nunes, W.A.G.A, Menezes, J.F.S., Benites, V.M., Lima Junior, S.A., Oliveira, A.S., 2015. Use of organic compost produced from slaughterhouse waste as fertilizer in soybean and corn crops. Scienta Agricola, 72(4): 343-350, DOI: 10.1590/0103-9016-2014-0094.

[14] Announcement of the Speaker of the Sejm of the Republic of Poland of February 2, 2017, therefore. OJ 2006 No. 17 item 127, consolidated text, OJ 2017 item 242 (in Polish).

[15] Regulation (EC) No 1069/2009 of the European Parliament and of the Council of 21 October 2009 laying down health rules as regards animal by-products and derived products not intended for human consumption and repealing Regulation (EC) No 1774/2002 (Animal by-products Regulation).

[16] Regulation of the Minister of Agriculture and Rural Development on 18 June 2008, on the implementation of certain provisions of the Act on fertilizers and fertilization. OJ of Laws 2008 No. 119, item 615, as amended (in Polish).

[17] Sobczak, A., Błyszczek, E., 2009. Ways of management of by-products from meat industry (in Polish). Czasopismo Techniczne. Chemia. R. 106, z. 1-Ch: 141-151.

[18] Vandecasteele, B., Reubens, B., Willekens, K., De Neve, S., 2014. Composting for increasing the fertilizer value of chicken manure: Effects of feedstock on P availability. Waste and Biomass Valorization, 5: 491-503, DOI 10.1007/s12649-013-9264-5. 